\title{
INFORMATION COMPONENT OF INNOVATIVE SUPPORT FOR AGRICULTURAL ENTERPRISES CAPITAL
}

\author{
Oleksandr Karamushka', Svitlana Moroz ${ }^{2}$, Natalia Vasylieva ${ }^{3}$
}

\begin{abstract}
The importance of researching the information component of innovative capital support is due to the formation of the knowledge economy and the need to increase the competitiveness of domestic agrarian enterprises. Innovative renewal of the capital of agrarian enterprises is a key to improving the efficiency of their work: increasing production and sales, reducing production costs, and increasing productivity. At the same time, the problem of the influence of the information component of innovation on capital remains open, which is a reserve for increasing the efficiency of its use and allows us to develop approaches to ensure the profitability growth of agrarian enterprises. Separate aspects of the use of innovations in the agrarian sector of the economy were considered by J. Sayer, K. G. Cassman, H. van Es, J. Woodard, G. Ye. Pavlova, and others. The aim of this article is to research interconnections that arise between the information component of innovation and types of the capital of an enterprise, taking into account agrarian specificity. Methodology. During the research and writing of the article, methods were used: monographic, abstract-logical, mathematical statistics, observation. Results. Any innovation is dual in nature, including the material foundation and the information component. Innovation on the impact on economic processes of enterprises appropriately divided into production (technical, technological, chemical, biological, and managerial) and sales (product and marketing). According to the results of the research, the scheme of the influence of types of innovation on the types of the capital of agrarian enterprises was developed. Empirical studies have shown that the information component of production innovation is methodical and instructional documentation, warranty contract obligations, production licenses, patents, plant and animal breed rights, databases and electronic services of an innovator with their offers, automated information management systems of the enterprise, staff training programs. The information component of sales innovation are the certificates of products quality, brands and trademarks, the standards of the quality of products of the importing countries, characteristics of target market segments, automated customer databases, licensing agreements for the sale of product, data on monitoring of the sectoral markets, pre-contracted deliveries of products, tools e-commerce, etc. Conclusions. The information component of various types of innovation that are inherent in agrarian production is considered. Relationships between types of capital and innovation are explored. The specificity of the use of the information component of innovation in the sectoral section is analysed on the example of grain production and pig farming. The scheme of complex innovative support of enterprise capital is offered. The information component of innovation is detailed. It is recommended to use the information component in full, taking into account the sector specificity of agrarian enterprises.
\end{abstract}

Key words: agrarian enterprises, sources and types of capital, information component of innovations, sectoral specificity of innovation support.

JEL Classification: Q19, O31, D24, D8

\section{Introduction}

The agrarian sector plays an important role in the national economy, providing the population with food, as well as while processing enterprises worth raw materials. Itbrings stableincome and currency revenues to the budget

\footnotetext{
Corresponding author:

${ }^{1}$ Dnipro State Agrarian and Economic University, Ukraine.

E-mail: karamushka.o.m@dsau.dp.ua

${ }^{2}$ Dnipro State Agrarian and Economic University, Ukraine.

E-mail: moroz.s.i@dsau.dp.ua

${ }^{3}$ Dnipro State Agrarian and Economic University, Ukraine.

E-mail: vasylievaN@i.ua
}

and promotes the development of rural areas. However, there is a significant differentiation of performance indicators and environmental friendliness of individual producers, indicating management problems. One of the key elements in ensuring the economic development 
of agrarian enterprises and the competitiveness of their products is the rational application of innovation for the use, attraction, and increase in capital. In a context of globalization and the modern knowledge economy, the effectiveness of innovation depends on comprehensive and high-quality information support at all stages of their implementation, from analysis of proposals and target selection to practical use. World experience shows that innovative modernization of capital for enterprises in general, and agrarian ones in particular, is an important factor in increasing production and sales volumes, reducing the cost of production, increasing investment attractiveness, enhancing productivity and profitability. Therefore, the issues of innovative capital support are very important.

Separate aspects of increasing the efficiency of production on an innovative basis are the purpose of research of both domestic and foreign scientists and practitioners. In particular, Ye. A. Romanenko and I. V. Chaplia investigated the peculiarities of the innovation mechanism and the innovation engineering at the enterprises (Romanenko, Chaplay, 2016). In the work, S. Khalatur proposed an innovative doctrine of agricultural development in Ukraine based on the synergy process of the three basic strategic elements: human resources, innovation and environmental factors (Khalatur, 2017).G. Ye.Pavlovainvestigated thelevel and feature of management in the innovative development of the agrarian sector and its influence on economic growth and the formation of bioeconomics (Pavlova, 2015). J. Sayer and K. G. Cassman, studied innovation in agricultural production, which helps to increase the productivity of land use and quality of food products without increasing the pressure on the environment (Sayer, Cassman, 2013). H. van Es and D. Woodard, considering contemporary agriculture through the prism of digital technology, emphasized the need for an integrated mix of innovation in production processes, analysis and forecasting, and human capital and knowledge of farmers (Van Es, Woodard, 2017). Nowadays agrarian enterprises are widely using innovation, but their potential is not entirely utilized, focusing only on the material component and neglecting the information one. Investigating the influence of the information innovative component on capital, as a significant reserve for improving the efficiency of its use, allows us to develop approaches to ensure the profitability growth of Ukrainian agrarian enterprises.

The research objective is to establish and justify the relationships that arise between the information component of innovation and the types of enterprise capital, taking into account the specifics of agricultural activity.

\section{Research methodology}

The theoretical and methodological basis of the research is the modern economic theory, the work of domestic and foreign scientists on the problems of using innovations in the production, management, and business processes of Ukrainian agricultural enterprises.

While writing the article, the materials of the Food and Agriculture Organization of the United Nations, the State Statistics Committee of Ukraine, the Ministry of Agrarian Policy of Ukraine, the proposals of innovators and the experience of using innovations by domestic agricultural enterprises were used.

The research used the following methods: monographic (in the analysis of modern scientific research using innovations in the work of agrarian enterprises) abstractlogical (with theoretical generalizations and formulation of conclusions); mathematical statistics (selective, series of dynamics in the study of the state and the identification trends in the production and marketing of agricultural products) observation (in the analysis using innovations by domestic enterprises).

\section{The influence of innovation on the types of the capital of enterprises}

Capital is a set of monetary, material, and intangible resources of an enterprise, which are involved from different sources for applying in production, marketing, and investment processes in order to generate income. The capital of the company consists of the main, turnover, intellectual, human, and social ones. The basic capital of agrarian enterprises includes land, buildings, and structures of agribusiness, agrarian machinery and equipment. Working capital contains cash, crop material, fertilizers means, plant and animal protection, feed, fertilizers, biologically active additives, chemical support, and so on. Intellectual capital is a general set of knowledge, experience, relationships, which can bring profits or benefits to the company. The intellectual capital of agrarian enterprises includes copyrights for plant varieties or breeds of animals, patents, author's certificates, technical documentation of agricultural production, trademarks, logos, software tools for automation of production and sales. Human capital covers a set of skills, knowledge and personal qualities of individual employees and the whole personnel. Social capital is represented by relationships between the enterprise and its partners and client line enterprises its image and business reputation.

On the basis of belonging and sources of income, there exist own and borrowed capital (Andriychuk, 2013). Equity is a means of production and sales belonging to the owners of the enterprise. In the process of economic activity, it grows at the expense of the profit or decreases, compensating losses. The borrowed capital is invested by the third parties on the terms of return and payment for use. The borrowed capital includes loans, issued bills, payables, leasing equipment, labour resources involved in outsourcing, franchise, and the like ones.

In the conditions of integration and globalization, Ukrainian agrarian enterprises should follow the world 
tendencies of innovative development of agriculture. Innovation in business processes can be divided into production and sales ones. The first group involving: technical, technological, chemical, biological and managerial innovation. The second group includes: product and marketing innovation.

The purpose of implementing innovation is to support (improve) the formation, attraction, development, and rational use of capital. Any innovation is dual in nature, that is, it consists of a material basis and an information component. Integrated innovative capital support of an agrarian enterprise requires establishing of links between types of innovation and capital, as reflected in the author's result in Figure 1.

The basic capital is affected by technical, technological, and managerial innovations, which are aimed at the purchase and use of energy and resource-saving technologies and management systems, directed to the automated production process. The working capital is associated with biological, chemical, managerial, and product innovation, including high-yielding varieties and breeds, means of plant and animal protection input, inventory management and product quality management.

Intellectual capital is under the influence of technological, managerial, and marketing innovation that facilitate the definition of strategic benchmarks in the production and sales activities of the enterprise. Human capital relies on the introduction of technological, managerial, and marketing innovations aimed at the professional development of personnel. Social capital is formed under the influence of managerial and marketing innovations, which help in improving the enterprise's image and business reputation and increasing its value in the development of rural communities.

The information components of technical, technological, chemical, and biological innovation are methodical and guidance documents reflecting with the peculiarities of their implementation and application, warranty obligations, quality certificates for consumables, production licenses, patents, plant and animal breed rights, databases and electronic services of innovators with their offers (veterinary medicines, means of protection). Information components of managerial innovation is a set of information flows of the enterprise and software for collecting, processing, and transmitting data between units of management and investors, automated means of production process management, in particular, information systems in accounting, decision support, electronic document turnover tools, staff training programs. The information components of product innovation are the quality

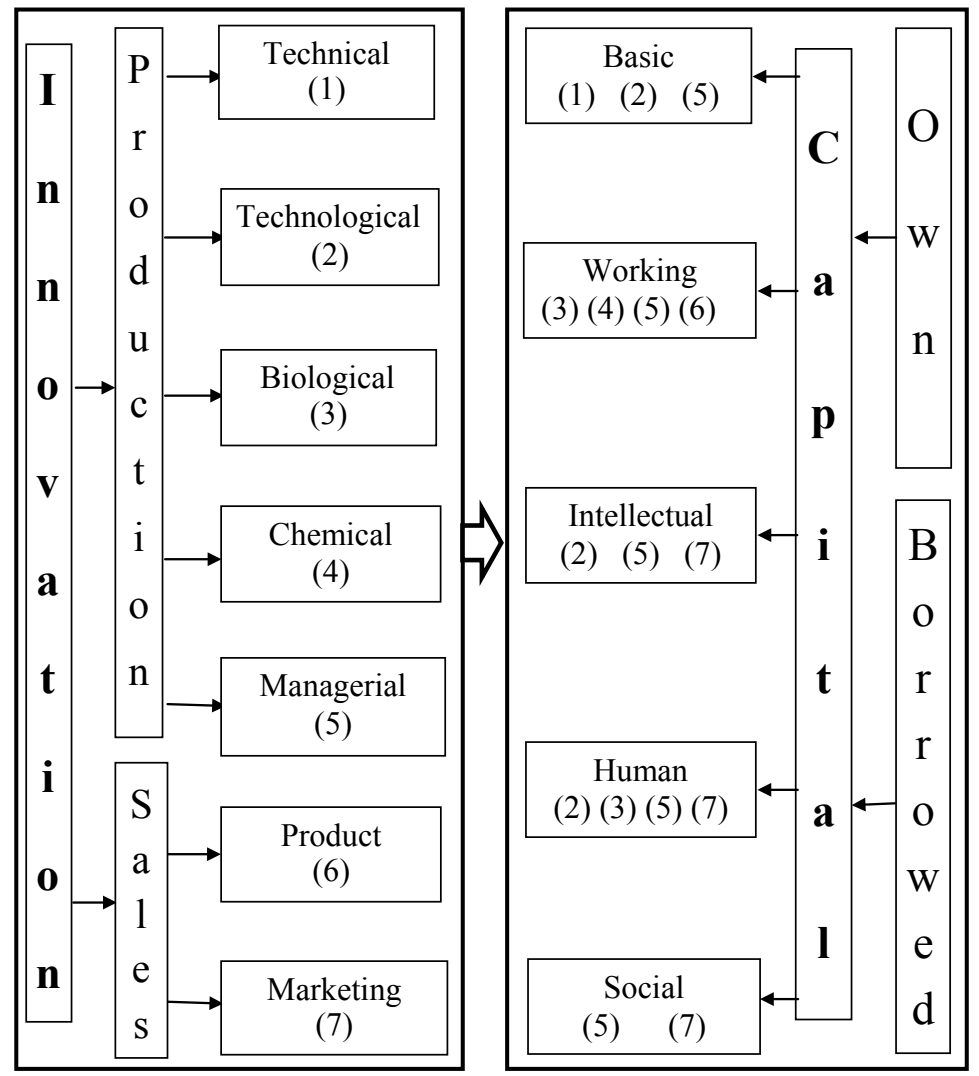

Figure 1. Scheme of complex innovative support of the agrarian enterprise capital

Source: compiled by the authors 
certificates of manufactured products, brands and trademarks, product quality standards of importers, characteristics of target market segments. Information components of marketing innovation are automated customer databases, license agreements for sales, analytical reviews and forecasts for sectoral markets, preliminary contracts for the supply of products, contracts for the lease of warehouse capacities or charter carriers, electronic means of sale.

\section{Practical use of information components of innovation}

We will describe using information components of innovation taking into account the sectoral differences in Ukrainian agriculture.

One of the leading sub-sectors of plant growing is grain production with an average profitability over the past 3 years at $36 \%$. This is due to the large volumes of cultivated lands, significant export potential, and demand for Ukrainian grain in foreign markets. Grain group is represented by three main crops: wheat, corn, and barley. In the course of the study, it was found that wheat belongs among the grain crops in the territory of Ukraine because it is in high demand, brings annually 50-60 billion UAH of income is profitable with a profitability level of $11 \%$ on average over the past 10 years (ukrstat.gov.ua, 2017). Large annual wheat collections amounting to 23-25 million tons allow Ukraine to traditionally enter the TOP-10 countries of the world in terms of its production capacity, with an export potential of about $70 \%$ of the total grain yield (15-17 million tons). However, because of the natural and climatic conditions of Ukraine, wheat cultivation is risky. In unfavourable years, grain producers harvest only 15-16 million tons of grain, which leads to losses of about 18-20 billion UAH their income (ukrstat.gov.ua, 2018).

Based on the processing of statistical data, it was established that the second stage in grain crops in Ukraine belongs to the production of corn. This is due to the rather high average yield of this crop at the level of $60 \mathrm{c} /$ ha (ukrstat.gov.ua, 2017). Annual production ranges from 25-28 million tons and provides income at the level of 40-50 billion UAH, with exports up to 70\% (16-20 million tons). Even in adverse years, yields at the level of $40 \mathrm{c} /$ ha allow you to get income on a par with 30 billion UAH (ukrstat.gov.ua, 2018).

There are three of the leaders in the production of barley, the annual income of which is more than 20 billion UAH. The gross barley harvest of more than 9 million tons allowed Ukraine in 2014 to be among the top three world leaders in terms of its production. About $40-50 \%$ or $4-5$ million tons of harvested barley is destined for export. However, the production of barley is also risky, because in recent years its cultivation was sometimes even unprofitable. Even the maximum yield of spring barley $(33 \mathrm{c} / \mathrm{ha})$ in Ukraine is only $30 \%$ of the genetic potential of modern varieties, which means that agricultural enterprises lose about 4 billion UAH of income in unfavourable years (ukrstat.gov.ua, 2018).

In the leading countries of the world, due to the implementation of innovative technologies, the yield of grain crops is up to $50 \%$ higher than in Ukraine in favourable years. Thus, the main task of the workers of the agrarian sector is to increase the productivity of each hectare of crops, because, without the use of innovative agrarian technologies, domestic grain producers receive only 25 to $40 \%$ of the genetically possible grain yield (depending on the grain crop) (FAO, 2018).

The process of grain production and marketing can be divided into five stages: preparatory (soil tillage, fertilization, selection of seeds), sowing campaign, caring for crops (growing crops, protecting against weeds and pests), harvesting (harvesting, delivering to the place of refinement and storage) and distribution (conclusion of contracts, advertising campaigns, and sales).

Information components of innovation to the first stage include: information systems for supporting parallel driving, GPS navigation technology of autopilot and differentiated applying of chemicals, tracking techniques, and fuel consumption control, electronic maps and logistics, operational analysis of the results of satellite field monitoring, systems of decision-making support bases on the recommended varieties and hybrids of grain crops, centralized information systems in the control of production processes, software for training personnel.

For the second stage of crop production, it is advisable to use the information innovative components of innovation, such as: interactive systems of GPS navigation to control the speed of sowing machinery, expenditures of seeds and fertilizers, weather monitoring systems to optimize terms of cultivation.

Relevant informational components of innovation to the third stage are: methods for calculating norms, timing and schemes of applying fertilizers and plant protection means obtained from drones' check of grain crops, autopilot technology with RTK stations, which ensure the accuracy of applying fertilizers and chemicals from 10 to $2.5 \mathrm{~cm}$.

On the fourth stage of grain production, it is promising to use the information components of innovation aimed at: optimizing the technology routes during harvesting, taking into account grain yields to, the system of express grain assessment for its further storage and bringing to the condition on its own leased capacities, obtaining quality certificates for sales, in accordance with the contractual demands.

At the fifth stage, the actual distribution of innovative information components are designed to maintain sales of cultivated grains with maximum benefit, by means, the analysis of regional markets by e-commerce, the placement of lots for online trading, for example, on the site https://graintrade.com.ua/. 
The meat production cluster in the livestock sector of Ukrainian agriculture is oriented towards the domestic market with a low level of solvent demand, which provides annual consumption of $51.4 \mathrm{~kg}$, which is $36 \%$ lower than the physiological norm. In the structure, as production and consumption, the leading are poultry meat, then the pork, and significantly inferior beef. Poultry meat production is mainly concentrated in industrial complexes. Beef suppliers are households.

Pig farming is more interesting for innovation management. Statistical data indicates a low profitability of the industry at $0.2-12.6 \%$ in $2012-2015$ and unprofitability of $4.1 \%$ in 2016 (ukrstat.gov.ua, 2017). An important factor is a growth of methane emissions and air nitrogen precipitates and environmental pollution. Accordingly, innovations in pig breeding should be aimed at increasing the profitability of pork growing and marketing and the environmental aspects of the industry.

Hence, innovation in pig farming should be primarily aimed at increasing the profitability of hogs raising and pork marketing and committed to the contemporary environmental standards.

In this case, the informational components of technical innovation are the methodical materials on the constructing and equipping pig farms, the system of electronic animals' identification using subcutaneous microchips, electronic boxes, boluses, software for managing production processes.

Technological innovation is necessary to improve animal breeding programs and increase feed conversion through differentiated formulas and feeding forms for different sex-age groups of hogs.

The information basis for the use of biological innovation is the databases of high-yielding breeds of pigs facing demands of food market segments, genetic characteristics of the main herd of the enterprise and breeding puppets.

Information components of chemical innovation include veterinary and sanitary support for production, namely, the introduction to new methods of prevention and treatment based on automated animal health monitoring systems to reduce mortality and prevent epidemics, for example, based on the current information at the portal http://pigua.info.

Management innovation should focus on reducing non-productive costs. It covers free software, (arranging production programs for raising animals in OpenProj, preparation of documentation in Writer, analytical and predictive calculations in Calc) and modelling tools for inventory management, determining the optimal feeding rate for each pig genital age group, etc.

The information components of product innovation in pig breeding are the differentiated purchase prices of processing enterprises and requirements for age, weight, and quality animal conditions.

Information components of principal marketing innovation are optimization of logistic sales flows by localization of production capacities around primary processing enterprises (slaughter factories) and sales on a cooperative basis. A promising means of marketing can be the adoption of electronic clients' orders for piglets, for example, using a profile in social networks.

\section{Conclusions}

During the research, the following were specified: technical, technological, chemical, biological, management, product and marketing innovations taking into account the industry specificity, which made it possible to make a number of conclusions.

Solving the problem of using innovation for own and borrowed capital largely depends on the structure and scale of production of a particular enterprise and its resource component.

The vectors of influence by types of innovation on types and sources of capital are substantiated, which will allow optimizing the choice of innovation for its modernization and attraction. In Ukraine, grain production is traditionally an export industry. In order to increase the quality of grain production and its export, enterprises should focus on the development and attraction of intellectual and fixed capital. Also, grain producers have to evaluate the social aspect of their activities, that is, to assess the environmental consequences, preventing excessive chemicalization and depletion of the soil.

With respect to equity in a pig farm, innovations are expediently aimed at increasing the productivity of production and reducing costs, implementing new production and marketing technologies, creating and using different databases, applying professional and free software, and training of employees. The implementation of innovation aimed at reducing air water, soil pollution with waste is also relevant.

On the basis of the innovation analysis in grain production and pig farming, it is possible to find common features for the borrowed capital in the form of leasing and basic capital, lending - for advancing working capital, franchising - for intellectual, outsourcing - for human, crowdsourcing and branding - for social capital. The prospect of raising funds for grain growers is the futures agreement. Investors of pork producers may be processing enterprises when concluding long-term contracts.

Based on the research, recommendations were given on the use of information components of innovation to support the capital of agrarian enterprises in the production of grain and pig products.

The information component defines the parameters of use and implementation of innovation, in particular, the ways and conditions of application, the need for integrated communication with other innovation for synergistic effects on types of capital, etc.

Further research will be aimed at transferring the results to other sub-sectors of agriculture in Ukraine. 


\section{References:}

Romanenko, Y. A., Chaplay, I. V. (2016). Modern administrative tool of the innovative development of the enterprise (Scientific bulletin of Polissia), no. 8, p. 2, pp. 268-275. (in Ukrainian)

Khalatur, S. (2017). Innovative doctrine development of agriculture growth of Ukraine (Technology audit and production reserves), vol. 4, no. 36, pp. 19-26.

Pavlova, G. Ye. (2015). Innovative development of the agrarian sector of the national economy: theoretical foundations, methodology, mechanisms of the management. Kyiv: DKS Tsentr. (in Ukrainian)

Sayer, J., Cassman, K. G., (2013). Agricultural innovation to protect the environment. PNAS, Vol. 110, No. 21, 8345-8348. Retrieved from: http://www.pnas.org/content/110/21/8345.

Van Es, H., Woodard, J. (2017). Chapter 4: Innovation in Agriculture and Food Systems in the Digital Age, in "The global innovation index 2017. Innovation Feeding the World", tenth edition, Geneva, Switzerland, 97-104. Retrieved from: http://www.wipo.int/edocs/pubdocs/en/wipo_pub_gii_2017-chapter4.pdf.

Andriychuk, V. H. (2013) Economics of enterprises of agricultural sector. Kyiv: KNEU. (in Ukrainian)

Statistical Yearbook "Agriculture of Ukraine for 2016" (2017). In O. M. Prokopenko (Ed.). Kyiv: State Statistics Service of Ukraine (in Ukrainian). Retrieved from: http://www.ukrstat.gov.ua

FAO (2018). Crops. Retrieved from: http://www.fao.org/faostat/en/\#data/QC

Statistical Yearbook "Crop production of Ukraine 2017" (2018). In O. M. Prokopenko (Ed.). Kyiv: State Statistics Service of Ukraine (in Ukrainian). Retrieved from: http://www.ukrstat.gov.ua/ 